KHRYPKO SVITLANA, Candidate of Sciences in Philosophy, Associate professor, Philosophy department, Borys Grinchenko Kyiv University

\title{
THE VALUED FOCUS OF A WIDOW AND AN ORPHAN STATUSES AND SCALE OF PROTECTION IN THE OLD AND NEW TESTAMENT TRADITION
}

The article is devoted to a problem of a widow's place, status, scale of protection and vulnerability consideration due to the biblical tradition. Moreover, it discovers a problem of widows' and orphans' solitude and their incorporation into social life. Some ambiguity of a widow's place and role in ancient tradition is highlighted. The various contexts of a widow's image understanding are considered. The multi-vectoral focuses of a widow's image presentation in Biblical context are analyzed. The diverse contexts of solitude, exclusivity, devoted life, vocation, abandonment and protection at the same time, Heaven's protection are conceived. Presented factors of a widow's status are compared with the statuses of orphans, levits, foreigners, etc. The work is based on methodical description of the women' images who are selected from the Old and New Testament. Particular attention is given to Ukrainian context of a widow's image spiritual and semantic understanding.

Key words: widow; value; image; axiology; orphan; symbolic; semantic; solitude; exclusivity; protection; separation; intercession.

The significance of the issue. A girl - woman (wife) mother, all the statuses are included into a threefold issue which has been a crucial point for any nation's worldview.

A woman's image has always embodied an idea of motherhood, an idea of life, an idea of bloodline assurance, etc. The magic of sensuality and participation in a mystery of birth has led to careful and confidential attitude to a woman.

Nevertheless, in this "festival of life" an image of another women category has been highlighted. It is a woman-widow, who has obtained a special attitude, special status attributes, and special rites' functions, occupied an ambiguous place in social conscience.

The consideration of a spiritual widow's status has some difficulties and superstitions. Namely, a true ancient understanding of a widow's image has been lost in repeated translations of the Bible texts. However, it can be stated that the key ideas which are the grounds of a widow's image in the Bible have remained untouched. For instance, a typical attribute is a constant parallel coherence of a widow and an orphan protection on the Bible's pages.

The priorities are to provide a philosophical consideration of a widow's image sacral context in the Bible tradition and to find out a widow's spiritual status.

The analyses of recent studies and publications. Robert Strand applies to the problem of a widow's status in his works [Strand, 2016a; Strand, 2016b]. Namely, he has conceived a special attitude to a widow through analyses of women' images in the Old and New Testament. A special style narration about the Biblical women should be noticed. That style can be conditionally named as a Midrash. The word has its roots in the verbs "to research", "to find out", "to discover". The Midrashes were the result of Hebrew scientists work, who looked for a true meaning of holy texts and their applications in modern world. The most of modern Midrashes have appeared on the base of synagogues' sermons in order to fill the blank places in holy texts [Strand, 2016b: 7]. The Bible histories of women are extremely short in the author's vision of Robert Strand. The author has an original idea to narrate in the first person to give an opportunity for us to hear the women' voices [Strand, 2016b: 8].

The ground based analysis of Judith widow's image [Jud. 9:4-5, 10:3] has been given by English researcher Makrina Scott [2003]. The accents of power, greatness, loneliness, and almost king's authority have been put in a close parallel with an acknowledgement of a widow's protection of Heaven.

The comparative analysis of a widow's image in Ukrainian and Biblical traditions is in a focus of S. Khripko paper [Khripko, 2012].

The loneliness phenomenon as a context of a womanwidow existence is followed in M. Movchan work [Movchan, 2009].

By contrast to the works in which a widow's image (and peripherally an orphan's one) are considered in context, we fundamentally raise an issue of a widow's status and image in the Biblical tradition.

The main aim of the work is to analyze the specific features of a widow's image and status on the Bible pages, to consider semantic contexts of an image, to follow the parallels between the images of an orphan and a widow, to conceive a loneliness phenomenon and orphans' and widows' protection on the holy texts' pages.

A Widow's Image on the Bible Pages.

A "widow" according to Biblical norms and Judaic moral principles is a woman who all her time has devoted to a child and God after her husband's death, for this reason she is not searching another man or wasting time on friends, entertainments, or on herself.

We would like to underscore that the issues of a widow and an orphan on the Bible pages are complicated ones and thereby are central. Both the Old and New Testament are riddled with the idea of widows' and orphans' God 
protection who (according to the prophetic words or direct speech of Jesus) are guaranteed immediate defense. This theme is mentioned more than 20 times with diverge valued accents, notably they are:

- A semantic way of misfortune fruition and plight,

- An issue of warning about punishment,

- A question about status,

- God-devoted life theme,

- A warranty of Heaven's protection [Khrypko, 2012].

Consequently, in the Old Testament, particularly in Exodus the tough and adamant prohibition of offending the most defenseless human in that society - a widow, can be met (thereby, deliberately or unintentionally is not important): "Do not mistreat any widow or orphan. If you do, I, the Lord, will answer them when they cry out to me for help" [Exo. 22:22-23]. In this part we can follow the idea of divine punishment for a foreigner's, widow's or orphan's offend or oppression with shifting their social status: "I will become angry and kill you in war. Your wives will become widows, and your children will be fatherless" [Exo. 22:24].

The highlighted issue of God defense glory and punishment for widow's mistreat and her rights distortion are mentioned many times in Deuteronomy: "The Lord your God is supreme over all gods and over all powers. $\mathrm{He}$ is great and mighty, and he is to be obeyed. He does not show partiality, and he does not accept bribes. He makes sure that orphans and widows are treated fairly; he loves the foreigners who live with our people, and gives them food and clothes..." [Deu. 10:17-18; 11:29; 16:11; 24:17; 25:5-10; 27:19].

In such context a famous cry of righteous Job to God is significant: "I have never refused to help the poor; never have I let widows live in despair" [Job 31:16].

In the David's psalms undoubtedly mentioned who is supported by God on life road: "He protects the strangers who live in our land; he helps widows and orphans, but takes the wicked to their ruin" [Psa. 146:9]. The idea is followed in Proverbs: "The Lord will destroy the homes of arrogant men, but he will protect a widow's property" [Pro. 15:25]. Therefore, a widow's house is guarded by God himself. The widows' protection is guaranteed due to the word of Isaiah prophet: "and learn to do right. See that justice is done-help those who are oppressed, give orphans their rights, and defend widows" [/sa. 1:17]. A strict ban of widows and orphan oppression is put into the speeches of prophets Jeremiah and Zechariah [Jer. 7:6; 22:3], [Zec. 7:10]. The same tendencies of the God's judgement are in the words of prophet Malachi: "I will appear among you to judge, and I will testify at once against those who practice magic, against adulterers, against those who give false testimony, those who cheat employees out of their wages, and those who take advantage of widows, orphans, and foreigners-against all who do not respect me" [Mal. 3:5].

A widow's image is a complex one, in literally interpretation and symbolic allusions in the Old and New Testaments. In the words of the deuterecanonical book of the Old Testament - a book of Baruch according to the leading biblical researchers, a widow's image had been posited in general as an embodiment of typical case of misfortune that a man or society could come across in the case of separation with God. Hence, due to God eternal laws violations, Jerusalem had obtained the marks of widow's fate. Particularly, about the Jerusalem cry we are reading: "Let no one take pleasure in my suffering now that I am a widow and so many of my children have been taken from me. They turned away from God's Law, and their sins have made me a deserted city. They had no respect for his commandments and would not live by them; they refused to let him guide them in the way of righteousness. All you neighboring cities come and consider how the Eternal God has sent my children into exile. He brought against them a nation from far away, a shameless nation that speaks a foreign language and has no respect for the elderly and no pity for children. These people carried off my beloved sons and took away my daughters, and I was left a widow, completely alone" [Bar. 4:12-16]. Such context of a punishment through reducing the social status to a widow's position that has been given for old people disrespect is traced also in prophet Isaiah book. Moreover in "Judgement on Babylon" we are finding: "You thought you would always be a queen, and did not take these things to heart or think how it all would end. "Listen to this, you lover of pleasure, you that think you are safe and secure. You claim you are as great as God - that there is no one else like you. You thought that you would never be a widow or suffer the loss of your children. But in a moment, in a single day, both of these things will happen. In spite of all the magic you use, you will lose your husband and children" [Isa. 47:7-9].

The significant issue in the Bible is a semantic meaning of "widow's clothes" [Jud. 8:4-6] as a sample of grief. On the one hand the idea of defenselessness demonstrated, on the other hand the lack of hope to give a birth (especially for the first-born child in the case when she remained unmarried) that in the old times supposed to be a great God blessing [Gen. 38:11-14; 38:19]. Thus Judah sent his daughter-in-law Tamar in the house of her father with the words: "Return to your father's house and remain a widow". "She changed from the widow's clothes she had been wearing" only in that moment when an hour came her to be a promised wife and a mother of the first-born son. When she had solved the problem she "took off her veil, and put her widow's clothes back on". The idea of widow's clothes as the clothes of pray and grief is expounded in the deuterecanonical book of Judith [Jud. 9:4-5; 10:3]. After desperate appeal to God: "O my God, listen to my prayer, the prayer of a widow". Judith "took off the sackcloth and her widow's clothes, took a bath, and put on rich perfumes. She brushed her hair, tied a ribbon around it, and dressed herself in the fine clothes she used to wear on joyful occasions when her husband Manasseh was still alive."

The image of a widow Judith is extremely interesting, especially due to the fact of its presence exceptionally on the pages of Deuterocanonical books and according to the contexts of Judith life [Jud. 15:11-13, 16:18-23]. 1- She was an embodiment of a classical widow, as she stayed unmarried and had a fairly solitary life. 2- Having made a distance of active social life, she immediately returned to it when she had realized her necessity. 3- She had defied local authority who, as she considered, abused power. 4- The authorities had come to her (a woman and a widow) with a request for assistance. 5- She had personally solved a problem of mortal danger for her nation with the help of pray and protection of Heaven. 6- She worked in a close cooperation with her servant (slave), whom had been given a personal freedom. 7- She was an embodiment of greatness and power of a woman. Moreover, she was a bright example of marital fidelity and first love loyalty [Scott, 2003: 223-232].

Furthermore, we would like to draw reader's attention to a problematic context of a widow's tears phenomenon. Widow's tears owing to the Biblical accents are considered to be taken into account as a crucial measure at the God's judgement combining the reasons of deeds and the consequences. In Deuterocanonical book of Sirach we are finding: "The Lord is fair and does not show partiality... When orphans and widows pour out their prayers, he does 
not ignore them. The tears running down a widow's cheek cry out in accusation against the one who has caused her distress" [Sir. 35:14-15].

Tears of a mother-widow who had lost a sonbreadwinner were noticed by Jesus in public. Jesus as Elijah [1Ki 17:17-24] returned a widow her only son after a servant of Roman officer had been healed by one word and in the same way with a single word a son was gave back to a mother-widow: "Soon afterward Jesus went to a town named Nain, accompanied by his disciples and a large crowd. Just as he arrived at the gate of the town, a funeral procession was coming out. The dead man was the only son of a woman who was a widow, and a large crowd from the town was with her. When the Lord saw her, his heart was filled with pity for her, and he said to her, "Don't cry." Then he walked over and touched the coffin, and the men carrying it stopped. Jesus said, "Young man! Get up, I tell you!" The dead man sat up and began to talk, and Jesus gave him back to his mother" [Luk. 7:11-15]

Moreover, the significant, for further consideration, is the fact that a widow had a guaranteed level of material support from the community and was equated with the priests - levites and orphans. In Deuteronomy where Church taxes, tithes are described and various variants their division, we are reading: "At the end of every third year bring the tithe of all your crops and store it in your towns. This food is for the Levites, since they own no property, and for the foreigners, orphans, and widows who live in your towns. They are to come and get all they need. Do this, and the Lord your God will bless you in everything you do" [Deu. 14:28-29].

To speak evil against widows and orphans was forbidden, and notably to take widow's clothes (a cloak) as a deposit was banned. In that time a cloak was more than clothes, it contained every meaning of clothes: a person wore it, slept on it, covered by it, and, actually, it was only one outer clothing that a person possessed: "Do not deprive foreigners and orphans of their rights; and do not take a widow's garment as security for a loan" [Deu. 24:17]. Mainly for them all leftovers of fruits, vegetables, and grapes were left after they had been harvested: "When you gather your crops and fail to bring in some of the grain that you have cut, do not go back for it; it is to be left for the foreigners, orphans, and widows, so that the Lord your God will bless you in everything you do. When you have picked your olives once, do not go back and get those that are left; they are for the foreigners, orphans, and widows. When you have gathered your grapes once, do not go back over the vines a second time; the grapes that are left are for the foreigners, orphans, and widows" [Deu. 24:19-21].

The issues of God paternity, protection, and revenge after widow's property or labor usage are in the Psalm words: "God, who lives in his sacred Temple, cares for orphans and protects widows" [Psa. 68:5]. About those people who use opportunities to abuse power in order to distort widow's rights is written: "You are doomed! You make unjust laws that oppress my people. That is how you keep the poor from having their rights and from getting justice. That is how you take the property that belongs to widows and orphans" [Isa. 10:1-2].

The themes of God punishment for a dishonest pray "in the public's eyes" with a parallel disgrace of a widow are met in the Gospel of Mark: "Watch out for the teachers of the Law, who like to walk around in their long robes and be greeted with respect in the marketplace, who choose the reserved seats in the synagogues and the best places at feasts. They take advantage of widows and rob them of their homes, and then make a show of saying long prayers. Their punishment will be all the worse!" [Mar. 12:38-40].
The recognition of widowhood positive meaning is traced in the analysis of such images as Judith and Anna. In the end of the Old Testament period the tendencies of widowhood respect were brightly embodied in Judith figure and Prophet Anna. For instance, Judith had purposely chosen a widow's role and devoted her life to pray and penance [Jud. 8:4-8; 16:21-23]: "For three years and four months, Judith had lived as a widow. In her grief she built a little shelter on the roof of her house and lived there, wearing sackcloth. She fasted during that entire period except when fasting was forbidden... and no one ever said anything bad about Judith. She was a very religious woman. Judith lived on her own estate and for the rest of her life she was famous throughout the land of Israel. Many men wanted to marry her, but she never remarried after the death of her husband Manasseh". Her glory had increased more and more, but she became old in her husband's estate and died at the age of 105 . Her divine life was a warranty of Israel land, people peace and wealth: "As long as Judith lived, and for many years after her death, no one dared to threaten the people of Israel" [Jud. 16:25]. Judith was an example of striking contrast between woman's natural weakness and God power that supported her trough a widow's life.

Furthermore, Jesus had chosen a widow as a heroine of his well-known parable about a judge and amount of faith [Luk. 18:1-8]. The fact was that a widow was considered to be the most unprotected human of the society in the Jesus times in Judaic culture, according to that her rights were distorted pretty often. Due to religious tradition the prays were made three times a day, and some rabbis taught not to disturb God with a pray more than assigned amount of times in order not to get Him tired, like "an annoying widow" from a parable got tired an unfair judge. To continue the New Testament tradition, we would like to pay attention to the prohibition issue for widow's house destruction that is clearly highlighted in the Gospel [Mat. 23:14], [Mar. 12:40], [Luk. 20:47]. The theme of "the best deed before God's face" is in the letter of James: "What God the Father considers to be pure and genuine religion is this: to take care of orphans and widows in their suffering and to keep oneself from being corrupted by the world" [Jam. 1:27].

Returning to the parable about the widow and the judge, we would like to draw additional attention to the fact that when Jesus retold the unfair judge monologue the final reasoning phrase of the judge "If I don't, she will keep on coming and finally wear me out!" was a "soften" translation from Greek original that literally meant that the widow could put bruises under the judge's eyes, thus he would protect her to avoid physical damage. We would let ourselves to expound the author version of the phrase in a semantic light, it might be: "I will take her under my protection to prevent her showing off my unfair judgement (that can have consequences for me)".

The most well-known and vivid example of God's special attention to a defenseless woman is a story which is known as "two cents of a widow" [Mar. 12, 41-44; Luk.21, 1-4]. Due to Robert Strand "among all women in the Bible that woman is the most anonymous... The Bible exclusively mentioned a donation that had been left in the Temple [Strand, 2016b: 37]". The woman's story is a bright example how a person can trust to God, who has noticed the smallest gifts from the poorest people and their background [Strand, 2016b: 39].

Furthermore, returning to the Old Testament we would like to mention that the text of Song of Songs at the first glace (but only at the first glance) is weird and appeals to a girl who is the only child and her mother due to the details 
in the text is supposed to be a widow. Applying even elementary "symbolic language" knowledge "the external erotic" may be interpreted in other way. In accordance with an old legend that text was put in the Bible only due to a famous rabbi authority who banned to exclude Song of Songs from the Old Testament, as time would pass the right person would read it.

Nevertheless, even despite of the sacral respect and pray power a fate of a widow was not easy in any cultural and national tradition.

The semantic context is followed in the sphere of Ukrainian anthroponomics. For instance, mental and historical memory have remained such well-spread, even nowadays, Ukrainian surnames, which embodied ancient tradition of name given, namely a widow's son, a person who is brought up by a widow. A vivid example is in the following surnames: Vdovin, Udovichenko, Nenchin, Materinchin, Vdovets, Vdovchuk, Vdovichenko, etc. However, it is a separate issue of research from a sphere of religious anthroponomics.

\section{Conclusions, generalizations, analogues and perspectives}

To sum up all presented material some conclusions and generalizations can be made:

- There are some bases to highlight valued solitude of a widow which has become a powerful marker of a widow's place determination in spiritual existence. From our point of view, it is driven not only by property difficulties, but by existing experience of an early death of a husband (soul mate).

- Solitude, isolation, necessity of being alone [Movchan, 2009: 92; 94; 144] are the traits of moral and spiritual embodiment of a widow's state and status in biblical times.

- The attention should be drawn to valued ambiguity of a widow's image understanding in the sphere of biblical tradition. Such attitude has been developed due to the various range of widows' behavior. Consequently, widows' participation in social events or their ignorance depended on their correspondence to the high standards which were applied to an image of "pure (unmarried for second time) widow".

- From ancient times a fear of widows' offence has been existed, as a punishment will be inevitable. Such idea has the deeper roots than Christian moral and the New Testament admonishments.

- Biblical representation of a widow's image contains the following priorities: in her solitude [Bar. 4:12-16] she has embodied a typical example of misfortune and grief [Isa. 47:9]. The semantic meaning of widow's clothes [Gen. 38:14; Jud. 10:3] demonstrates double grief, namely she has no hope to be a mother and if she stays unmarried, she will be left without any protection. Owing to these factors a widow has obtained protection due to the law on the same base as an orphan or a foreigner [Exo. 22:2123; Deu. 14:28-29; 24:17-22]. Moreover, she has been guarded by God [Deu. 10:17], who has always heard her claims [Sir. 35:14] and taken her under his control [Psa. $67: 6 ; 145: 9]$. God can revenge, particularly because of humiliation [Psa. 93:6-10]. Woe betide to a man who has decided to abuse her weakness [Isa. 10:2; Mar.12:40]. Jesus and Elijah returned a widow her only son [Luk.7:11$15 ; 1 K i$ 17:17-24] and put his Mother Maria into the hands of his beloved pupil [Joh. 19:26]. During the period of early Christian Church formation a widow got an everyday support [Act. 6:1]. If a widow had no relatives [1Ti 5:16; Act. 9:36-39], a community ought to organize complete support as the real piety demanded [Jam. 1:27; compared to Deu. 26:12; Job 31:36]. The special respect was shown to a widow's state embodied in Judith figure and Prophet Anna [Jud. 8:4-8; 16:22; Luk. 2:36] who devoted their lives to God, pray and penance. These traits are crucial in a widow's image illustration.

- The semantic analysis of a Ukrainian word "widow" has shown various diminutive-hypocoristic patterns. The fact leads to a conclusion that a widow has obtained respect and a slight degree of fear in Ukrainian culture. An idea of woman's return to "unmarried, pure, lady life" can be assumed. Such style of life excludes any attempt of a second marriage and can be considered to be a state of "a real widow".

- In national and biblical traditions widow's humiliation is the greatest sin. Owing to this fact a comparison between Ukraine and "a widow in grief" composed by T. Shevchenko can be suggested to have deep semantic, cultural and spiritual roots.

Nevertheless, a widow's life and fate were not easy in any national and cultural traditions.

The Ukrainian context of a widow's image consideration is an issue of separate research. Religious and femininity are the main issues cored in all religious and spiritual acts of Ukrainian mentality. However, having established a parallel, we needed to notice that a widow's image was extremely complicated in spiritual culture and Ukrainian mentality [Khrypko, 2003: 174-189]. Obtaining experience of married life, of a husband's death, understanding lost opportunity of having children, returning virginity - virgin life, all these factors formed social attitude to a powerful "widow's pray". Consequently, it had been included into the main rite traditions, namely ancestral traditions, defense practices, funeral ones. Overall, a function of pray was a crucial one if we were going to consider a widow's role in society [Khrypko, 2012].

Significant sustained tendency for Ukrainian and Russian folklore was to compare a widow with a cuckoo and with another prophetic bird - an owl. The roots of it were in the words' semantic meanings. In the first variant a cuckoo is equated with a single mother, due to the second one a theme of afterlife connection is followed. A night owl eternally was connected with mysteries, dangers; it was a harbinger of misfortunes, etc. Although, even having had sacral respect and powerful pray a widow's fate was extremely tough for any person.

Moreover, the widow's symbolic has been embodied in the sphere of Ukrainian anthroponomics (the surnames Vdovin, Nenchin, Vdovchuk...). The fact has additionally underlined symbolic, historic, traditional constants and mental roots of a widow's issue in Ukrainian cultural tradition.

\section{REFERENCES}

1. Ogienko, Ivan [translat.] 2003. The Bible or the Books of the Old and New Testament. Ukrainian Bible Society, Kyiv (ukr).

2. The Bible (Contemporary English Version by Good News Translation), 1976. Published by American Bible Society Available at: www.bibles.org/eng-GNTD

3. The King James Version of the Holy Bible, published by "DaVince Tools". 2001. Available at: www.kingjamesbibleonline.org/ 4. Strand, Robert G., Mandryk, O. [translat.] 2016. Ready for Everything: Women of the Old Testament. Svichado, Lviv, 152 p. (ukr).

5. Strand, Robert G., Mandryk, O. [translat.] 2016. Ready for Everything: Women of the New Testament. Svichado, Lviv, 160 p. (ukr).

6. Scott, Makrina 2003. Bible Stories Revisited - Discover Your Story in the Old Testament [translated by Biblical and Theological Institute named after Saint Apostol Andrew]. Moscow, 277 p. (rus).

7. Khrypko, S. 2012. Personality and Image of a Widow in Ukrainian and Biblical Tradition. Scientific magazine of National Pedagogical University named after M. P. Dragomanov. Part №7. Religion and Cultural Studies. Philosophy: Scientific issues collection. Kyiv: National Pedagogical University, № 28 (41). P. 7-

\section{СХІД № 3 (155) травень-червень 2018 р.}


25. Available at: http://www.vuzlib.com.ua/articles/book/16669Postat_\%D1\%96_obraz_vdovi_v_ukra\%-D1\%97/1.html

8. Movchan, $\bar{M}$. 2009. Solitude as a Phenomenon of Personal Existence. RVV PUSKU, 265 p. (ukr).

9. Ksavie, Leon-Dufura [ed.] and Luplasi, Jean [ed.] and George, Avgustin [ed.] and Grelo Pier [ed.] and Gije Jacques [ed.] and Lakan, Mark-Francois [ed.] 2003. Dictionary of Biblical Theology [translat. from French]. Kyiv, Kairos, 1287 p. (rus).

10. Khrypko, S. 2003. Religious and Spiritual Contexts of Ukrainian Mentality: thesis of doctor of philosophy: 09.00.11. National pedagogical university named after M. P. Dragomanov. Kyiv, 189 p.

Хрипко Світлана,

кандидат філософських наук, доцент, Київський університет імені Бориса Грінченка

\section{ЦІННІСНА АКЦЕНТУАЦІЯ СТАТУСУ І ОБСЯГУ ЗАХИЩЕНОСТІ ВДОВИ І СИРОТИ В СТАРО-ТА НОВОЗАПОВІТНІЙ ТРАДИЦІї}

Постать жінки завжди асоціюється 3 таїнством дітонародження, материнством, продовженням роду. Це, апріорі, вічно актуальна тема як у житті всіх і кожного, так і в просторі науково-дослідного пошуку осмислення життя, сенсу життя, призначенння, життевого покликання тощо. Проблема материнства червоною ниткою проходить крізь долю кожної людини і крізь сторінки Святого Письма. Але є жінки, доля і ціннісний статус яких дещо по-іншому втілює і проблему шлюбу, і проблему вірності, і проблему можливості чи неможливості дітонародження, і проблему самотності, і феномен беззахисності і захищеності одночасно. Осмисленню аксіологічної полівекторності цих проблем і присвячена публікація. Ціннісний зріз репрезентації Біблійних жіночих образів є стрижневим фокусом уваги цієї роботи.

Пріоритети роботи полягають у забезпеченні філософського розгляду образу вдови образного сакрального контексту в біблійній традиції та з'ясування духовного статусу вдови.

Основна мета роботи - осмислення місця, статусу, обсягу захищеності і вразливості, обсягу самотності і задіяності вдови та сироти в просторі Біблійної традиції.

Meтоди. Робота базується на методичному описі жіночих образів, обраних зі Старого та Нового Завіту. Більше того, принципи порівняльного аналізу застосовуються для того, щоб виявити риси вдової образності в блоках історичних текстів та порівняти український контекст існування вдів з біблійним.

Результати. Проаналізовано питання статусу вдів і сиріт та шкали охорони. Основна увага приділялася наступним ознакам: самотність вдови, семантичне значення одягу вдови, показник отриманої охорони, їх права та закони, які гарантували соціальну підтримку, рівень поваги.

На відміну від творів, в яких зображення вдови (а також периферійно сироти) розглядаються в контексті, питання про статус і зображення вдови в Біблійній традиції було безпосередньо адресоване темі соціального визнання. Крім того, включено український контекст соціального ставлення до найбільш беззахисних категорій (особливо вдів та сиріт).

У результаті доведено, що підстави констатувати вартісну окремішність і потужний чинник сили місця вдови в духовному вимірі буття. 3 авторської точки зору, воно зумовлене не тільки власними труднощами, але й існуючим досвідом ранньої смерті чоловіка (дружини душі). Самотність, ізоляція, необхідність самій представляти родину є рисами морального та духовного втілення стану та статусу вдови в біблійні часи.

Зауважено невизначеність розуміння образу вдови в біблійній традиції, яка стала можливою через різноманітну поведінку вдів. Участь або неучасть вдів у соціальних заходах залежала від їх відповідності високим стандартам, які застосовувались до образу "неодруженої вдруге".

Показано, що основною формою участі вдови в активному суспільному житті є молитва. Вона входила в основні традиції обряду, а саме - передвікові традиції, практику оборони, похоронні. Акцентовано семантичну, історичну і духовну складність та глибину відомого Шевченкового ототожнення України зі "скорбною вдовою". Окрім того, зауважено, що стійкою тенденцією українського фольклору є порівняння вдови із зозулею та 3 іншою пророчою птицею совою. В першому варіанті містично спрацьовувало ототожнення зозулі й самотньої матері, а в другому - простежується тема зв'язку з потойбіччям.

Ключові слова: вдова; цінність; образ; аксіологія; сирота; символічність; семантика; самотність; обраність; захищеність; окремішність; заступництво.

\section{ЛІТЕРАТУРА}

1. Біблія або Книги Святого Письма Старого й Нового Заповіту: [переклад проф.Івана Огієнка]. Київ: Українське Біблійне Товариство, 2003.

2. The Bible (Contemporary English Version by Good News Translation), published by American Bible Society [electronic resource], 1976. URL: www.bibles.org/eng-GNTD

3. The King James Version of the Holy Bible, published by "DaVince Tools" URL: www.kingjamesbibleonline.org/

4. Стренд Роберт Дж. Готові на все: Жінки Старого Завіту: [пер. О.Мандрика]. Львів: Свічадо, 2016. 152с.

5. Стренд Роберт Дж. Готові на все: Жінки Нового Завіту: [пер. О.Мандрика]. Львів:Свічадо, 2016. 160с.

6. Скотт Макрина. Перечитывая библейские истории - открой свою историю в Ветхом Завете: [пер. англ. изд. Bible Stories Revisited - Diskover Your Stori in the Old Testamen]. Библейско-Богословский Институт св. Апостола Андрея, Москва 2003. 277с.

7. Хрипко С. А. Постать і образ вдови в українській та біблійній традиції. Науковий часопис НПУ ім. М.Драгоманова. Серія №7. Релігієзнавство. Культурологія. Філософрія: Зб. наукових праць. К.: НПУ імені М.П. Драгоманова, 2012. № 28 (41). С. 7-25.

8. Мовчан М.М. Самотність як феномен бутя особистості. Полтава: РВВ ПУСКУ, 2009. 265 с.

9. Словарь Библейского Богословия под редакцией Ксавье Леон-Дюфура и Жана Люпласи, Августина Жоржа, Пьера Грело, Жака Гийе, Марка-Франсуа Лакана [перевод с французского]. Кайрос: Киев, 20031287 с.

10. Хрипко С. Духовно-релігійні вияви української ментальності: дис... канд. філос. наук: 09.00.11; Національний педагогічний ун-т ім. М. П. Драгоманова. К., 2003. 189 с.

(C) Khrypko Svitlana

Надійшла до редакції 22.03.2018 